\title{
Governance in the European Union
}

\section{Anton Pelinka}

\section{From the viewpoint of Political Science, the European Union is a special case.}

The history of the still ongoing process of European integration is characterized by different periods:Dynamic developments have been followed by periods of stagnation ("eurosclerosis"). Sometimes the enlargement process has been emphasized - as it happened in 1973, 1981, 1986, 1995 and 2004; and sometimes the process of deepening, of making the member states more dependable on each other and on the Union. The Single Market and the Monetary Union are examples for an ongoing deepening. The history of the $\mathrm{EU}$ is full of periods many observers considered crises - and of periods seen as progress full of optimism.

The periods - the ups and downs of deepening and widening - underline that the EU is a work in progress, not finished, and also without a clear picture of what the EU would look like at its final stage. That has a lot to do with the difficulty to define what the $\mathrm{EU}$ is all about from the perspective of political science. Political science is familiar with the political system of states - federal or centralised. Political science is familiar with international organisations, established by sovereign states to find a common basis for tackling urgent problems. But political science is much less familiar with an entity between - between a federal political system and an international organisation. For that reason, political science 
had to learn to live with the $\mathrm{EU}$ as a rather unique and especially new phenomenon:

- The EU is more than an International Organisation and more than a confederation. The EU has some significant elements of a supranational institution. When the EU's decisions are binding the member states even against their will (like in many policies of the "first pillar", the European Community), the EU is a supranational organisation - and that means the $\mathrm{EU}$ is a federation.

- The EU is less than a federation. As long as the power to decide about the EU's policies stays with every member state (like in all the aspects of the "second" and the "third pillar" but also in all matters of changing the de facto-constitution, the treatises), the $\mathrm{EU}$ is not completely a supranational institution but has significant intergovernmental characteristics - that means the EU is a confederation.

- The Union's process of "deepening" implies the understanding of an ongoing process of federalisation. More and more power has been given to the Union - at the cost of member states' power. But that very process has come to a standstill due to the paralysis of the constitutional treaty's ratification procedure.

Political Science sees and interprets the EU in an ambiguous way. On the one side, the EU is in the realm of "Comparative Politics". The EU can be and must be compared with national political systems like the United States or India, Japan or Russia. On the other side, the EU is considered to be part of "International Politics" and as an international player not a "state", but an intergovernmental "organisation" - like the UN, like the African Union, like the Organisation of American States or like the Council of Europe. The $\mathrm{EU}$ is - in that respect-a kind of hybrid, linking two different approaches, representing two different political frames and playing in two different leagues.

The analysis of the EU as a political system makes it necessary to go beyond the traditional wisdom of political analysis. The EU does not fit 
into an understanding of institutional arrangements and political processes within the strict framework of "either" - "or". An interesting example of the EU's ability to live in two of seemingly contradicting worlds is the case of Greenland. Greenland, an autonomous region of Denmark, does belong to the Kingdom of Denmark - but not to the EU. Denmark is member of the EU - but the Danish region Greenland is not. Conventional wisdom would not accept such a seemingly inconsistent arrangement. And neither would conventional wisdom accept some of the realities of the Schengen agreement. This agreement, part of the EU's "deepening", has accepted the non-EU members Norway and Iceland (and soon Switzerland) as participants - but other EU-members do not participate. Conventional wisdom would expect that you cannot live in two different worlds - participating in the EU's Schengen program without being EUmember; and being EU-member but not participating in the Schengen program. The EU accepts in its Schengen freedom non-members. At the same time, member states are not interested in that freedom and are not willing to renounce the traditional right of sovereign nation states boundary control.

The EU is a "state" - and is not a "state". The EU is an "international organisation" - and is not an "international organisation". That may be called inconsistent. But without accepting such inconsistencies the reality of the European Union will not be fully understood. Studying the EU implies the acceptance of a reality going beyond the traditional concepts of political systems as well as of international organisations.

\section{The EU's political system reflects this ambiguity: Federal and elements are mixed with elements typical for a confederation.}

The EU's major institutions represent this kind of pragmatic ability to live with contradictions. These institutions remind observers of the tradi- 
tional arrangement of the separation of power - but a more precise interpretation makes clear the specificities of a particular European system of checks and balances:

- The Council (European Council, Council of Ministers) as the representation of national governments is first and foremost not federal. But when the Council - within the first pillar - decides by qualified majority, something supranational (and therefore federal) enters the picture of an assembly of sovereign princes. The Council as the assembly of national executives has legislative power - but it shares that power with the European Parliament.

- The European Commission as a body completely independent from the national governments is federal-especially with respect to the commissions monopoly to initiate decisions. But as the members of the Commission are nationally recruited, a national element enters the Commission's federal structure. The Commission is an executive branch - but it also enjoys the monopoly to initiate legislation.

- The European Parliament as a European wide, directly elected legislative body is the most federal actor in the EU's decision making triangle. But even parliament combines supranational with intergovernmental elements, especially with respect to the de facto national character the European parliamentary elections express. And the Parliament still shares its legislative power with the Council.

This particular mixture creates different viewpoints:Commission and Parliament are by definition interested to stress the federal elements and to promote further development into the direction of a federation. The Council by its very nature contradicts these tendencies. The "princes" the head of states or of governments respectively - are acting primarily out of national interests, locked into the logics of national politics; competing for national votes on the national political market; and defending national prerogatives under the terms of "national sovereignty" or "subsidiarity". 
This could be seen in the process leading to the "Constitutional Treaty": In the European Convention designed to draft a European Constitution, the representatives of the European Parliament (EP) were most vocal in pushing for more federal elements. It was the European Council - already afraid of the national backlash - that watered down some of the more federalising provisions. But the concession the Council made to national sentiments was not enough to secure the ratification process especially under the conditions of plebiscites. That the Council's position could not prevent national constituencies to stop the ratification process reveals the amount of pressure national governments have to consider when dealing with European matters.

The background of the divergence the EU institutions are representing implies the question of leading interests. The members of the Councils head of states respectively governments (European Council) or cabinet ministers (Council of Ministers) - are legitimated on the national level only. As the EU consists of liberal, competitive, pluralistic democracies only, any actor within the Council acts under the rules of a national political market. $\mathrm{He}$ (she) has to consider public opinion polls, media, electoral date, opposition - but always on the national level. He (she) acts as a national political actor on a transnational level. As he (she) will be measured by his (her) success or failure - by a national electorate, directed by national interests, the transnational level will always come second after the national level. He (she) survives politically only as long as he (she) satisfies national interest.

The Commission is not completely but at least more immune against pressure and inputs from national polities. Its members are nominated by national governments - a procedure reflecting national politics. But as the Commission has to be accepted and is controlled by the EP; and as the individual commissioners are bound to articulate and represent European and not national interests, the Commission is significantly more able to promote a transnational European agenda. The Commission is able to play 
the role of a "protector of the European idea". Once appointed, a commissioner does not depend on national interest - at least as long as he (she) does not think to become renominated after the tenure of five years.

The European Parliament is the only among the EU's institutions that is able to claim a direct democratic European mandate. The MEPs are elected directly on a date set by the EU. But as the MEPs are still elected on national tickets and their re-election depends on national politics, their interests are still linked to national politics. On the other hand: The EP (and with it its members) will always be the winner from any trend towards federalisation. The Council's loss is the Parliament's win. The lesser national veto powers are able to block European decision making in the Council, the more the EP is able to decide eye to eye with the Council. This creates an institutional interest for the EP to claim the role of a speaker for the Union - and not for its member states.

The members of the Council play in national leagues. The members of the Commission as well as of the EP are allowed to play - part-time, at least - in the Euro-League. But as long as any change of the present institutional arrangement within the $\mathrm{EU}$ can be blocked by one of the (presently) 25 member states, the weight of the national leagues must still be considered stronger than the weight of the already existing EuroLeague.

\section{The EU's governmental structure lacks especially one element any contemporary federation is built upon: a unified (and unifying) party system.}

The absence of a coherent European party system indicates - perhaps more than any other factor - that the EU has not (yet) become a political union in the sense of a federation. The process of European integration has been pushed forward by the consensus of moderate rightist (Conservatives, Christian Democrats - like Robert Schuman, Kon- 
rad Adenauer and Alcide de Gasperi) and moderate leftist parties (Social Democrats, Socialists - like Paul Henri Spaak, Sicco Mansholt and Jacques Delors). But the decisive role national political parties played for the whole integration process has not led to the integration of national parties in European parties. European parties do exist in name (like the European People's Party and the Party of European Socialists) - but not in reality. In reality, these parties are a lose umbrella over fully independent national parties. This is one benchmark to distinguish the US from the EU; a fully developed from a not fully developed political union.

There are party groups in the European Parliament and the main party families (Conservatives, Socialists, Liberals, Greens) seem to be unified by umbrella organisations called European parties and parliamentary party groups. But these parties don't fulfil the main function any modern political party has - recruiting the political personnel. This task still lies with the national parties.

The party groups in the EP have a significant role in permitting the Parliament to function. The party groups nominate the committees' members. The party groups negotiate procedural aspects. Out of the consensus between the main party groups comes the legitimacy of the EP's presidency. But beyond the internal role, the European parties - as party groups - play in the EP, the parties don't exist. Especially from the outside, they are not perceived as transnational entities. They are still the loosely incorporated assemblies of national parties.

But even in the EP, the party groups are competing with national parties for positions and influence in the EP's committees. Even within the EP's parliamentary party groups, the impact of national parties is significant. The parliamentary integration of national in transnational parties is far from finished - reflecting the still national constituencies the individual MEPs feel obliged to represent. National parties have not (yet) been transformed in transnational parties.

The absence of European parties can easily be seen in the absence of 
any coherent policy: In the case of membership negotiations with Turkey, for instance, there was neither a "conservative" nor a "socialist", neither a "liberal" nor a "green" position. The visible policy was British or French, Polish or Italian, Portuguese or Greek. There was no "socialist" European position - but a position of the French Socialists, more or less similar to the German Christian Democrats and not at all in consensus with the German social democrats. The position within the national party system, especially the position as a governing or as an opposing party, decided about the approach to the Turkish membership question.

It was the same in conflict over the Iraq war:British Labour did not side with Spanish socialists, but with Spanish conservatives. And French conservatives were united with German social democrats. National politics influenced the positions for or against a particular position - and not European politics.

The deepening of the European party system is the potential motor as well as the best possible indicator for the deepening of the EU. When the party families grow into parties; when the transformation of European parties from lose umbrella organisations into parties that are able to perform some of the core functions political parties, the Union will be more of a federation.

The case of political parties demonstrates the main reason for the present paralysis of integration: National parties are not interested in surrendering functions to their respective European party families - and neither are national governments interested in agreeing to any significant step towards Europeanization.

\section{The crucial steps towards a more federal governance are blocked by an alliance of rightist nationalism and leftist romanticism.}

As the setback of the European Constitution by the French and the 
Dutch voters reflects, EU's "deepening" has run into the opposition of an unholy alliance; of an alliance full of contradictions. On the one side, the EU is criticized as a "super-state", getting too much power over the member states still considered to be at the root of democratic legitimacy. But the EU is criticized at the same time for destroying the system of social welfare - for advocating a free market economy against state interventionism. The EU - so the critique - is not strong enough to oppose "neo-liberalism". But the EU is - so another critique - contradicting "national identity" as well as neglecting the national sovereignty still very dear to so many Europeans.

The enlargement of 2004 has brought into the EU 8 former communist states and the two Mediterranean island republics Malta and Cyprus. This step has made the EU much more diverse as it used to be: economically, due to the access of less developed nations; politically, due to the membership of countries with a much shorter history of democratic stability; and culturally, due to the integration of societies with not much link to the "Western civilisation" in Huntington's sense. The EU after 2004 looks very different from the EU as it was before 2004.

The enlargement of 2004 went on rather smoothly. The reason was the strong consensus among European elites that the EU has to live up to its promise to accept former communist states as soon as the fulfil the criteria of Copenhagen, formulated by the European Council in 1993: liberal democracy, rule of law, market economy. But even this widely accepted enlargement was accompanied by specific undertones of nationalism - from the new members and from the old as well - and of fear that this particular enlargement will jeopardize the results and even the preconditions of the (West-) European welfare state, rooted in the different nation states.

Anti-federalist sentiments have strong nationalist roots: The nationalistic attitude is to save "national sovereignty" (which is diminished already by EU membership) from "Brussels bureaucrats"; and to defend "national 
identity against the ghost of Brussels. "Brussels" has become synonymous for faceless technocrats out to destroy national identities.

Anti-federalist sentiments have an anti-capitalist flavour also: The freedoms of the single market, the Maastricht criteria, the Monetary Union, and the principle of free trade are considered "neo-liberal", designed to destroy the welfare state and to shift power from the poor to the rich. The EU is seen as the main promoter of capitalism and of free trade.

The nationalistic attitude is no surprise. The whole endeavour to integrate European nation states into an economic and political union is the very antithesis to nationalism. European integration is learning from history: to overcome nationalism as the driving (and destroying) force of Europe's past. The anti-federalist sentiments of nationalists are consistent with this basic conflict: nationalism and transnational integration are not compatible.

The anti-capitalist attitude is much less consistent. Of course, from the viewpoint of a traditional (or Marxist) socialism, the free market philosophy the EU seems to be bound to is not acceptable. But the more recent trend towards a more market oriented economy did not start in Brussels - it started within nation states, promoted by national governments like the UK's conservative government under Margret Thatcher and by the US administration under Ronald Reagan. The EU's orientation is within the global mainstream and not ahead of it.

The whole process of integration is not primarily oriented on a specific ("neo-liberal" or other) model of Europe. The first and primary goal is to overcome nationalism. And the first and primary goal of the Constitutional Treaty, signed in 2004 but not ratified, was promoting transnational decision making. The direction of decisions to be made would have been open - shaping Europe's future more in the fashion of free market or more in the fashion of a welfare state. The process of deepening was and still is to enable, to empower Europe as a democratic political system. The EU's Europe is an open society. But to shape that society with 
democratic means, the $\mathrm{EU}$ has to develop more transnational political instruments.

The traditional right fights European integration for the - from the viewpoint of nationalism - right reasons. Traditional sovereignty is in decline and will be even more declining thanks to any further European deepening. The traditional left fights European integration for the wrong reason - wrong from its own perspective: by blocking the shift of power from the member states to the EU, the left is preventing European policy making - in favour of national policy making. As the welfare state as it was developed after 1945 on the national level is facing more and more difficulties from the loss of balance between labour and capital within the nation states, those interested in regaining the balance should be interested to establish a political level beyond the nation state. To oppose further integration means preventing Europe of becoming a polity.

Anti-federalist sentiments have a clear common denominator: The rhetoric of the anti-globalisation movement. Rightist nationalists and leftist romanticists are united by the opposition to globalisation which jeopardizes illusions of national sovereignty, vague concepts of national identity, and the survival of nationally based welfare systems. The EU provides that right-left alliance of anti-federalists with a perfect enemy and scapegoat.

The unholy alliance of nationalism and socialism is nothing new to the European integration. In 1954, the European Defence Community was defeated in the French National Assembly by an opposition, consisting of nationalists and communists - united against the moderate mainstream of center-left and center-right. The first attempt to give (Western) Europe an instrument for an Common Foreign and Security Policy did not succeed. The first realistic concept of European armed forces, integrating national armies into one European army, failed - defeated by the opposition of two movements which had nothing in common but an enemy.

The example of the failure to establish a European Defence Community 
has been hounding the European integration process for half a century. The chance for a dramatic leap forward has not been used. The alliance of the far right and the far left was able to triumph. A strategic pattern had been set - from Paris, 1954, to Paris, 2005.

\section{The present standstill of European integration makes inter-governmentalists very pessimistic. But the mood of neo-functionalists can be more optimistic.}

The understanding of the specificities of the European integration process is summarized in different theories or schools. The criterion considered as decisive is the presumed (or denied) ability to overcome the priority of national decision making; the priority of national governments and their veto power in the whole process of integration.

- Inter-governmentalism is based on the assumption that any decisive development - in the realm of deepening as well as in the realm of widening - has to be based on the consensus of national governments. Nothing else will suffice. And as the willingness of national governments to go ahead is blocked by the French and the Dutch referenda, nothing can be hoped for in the foreseeable future. There is no way out of the dilemma national interests have created. And, principally: Why should national governments, anxious to preserve their nationally based power, agree to give away any significant part of that power?

- Neo-functionalism is based on the understanding that European integration is the result of a specific logic: the logic of the over-spilling fountain, of the cascade. To save the results of the last steps of integration, next steps have to be set. There may be setbacks, but as long as the national governments are not willing to destroy the Union as such, they are prepared to undertake even unpopular steps. For that reason, the present standstill can be overcome as soon as the 
Union's structure - designed for a community of 6 - will fail to work for a community of 27,28 or 29 .

Neo-functionalism provides observers with some reason to be optimistic. But euro-optimists have to rely on the concept of brinkmanship: The Union has to face an abyss. The major actors - especially the national governments - have to deal with a dilemma: either to accept the loss of national power, which goes against their inbuilt interest and natural instinct to preserve as much power for their own polity as possible; or to risk the undoing and the implosion of the whole integration, the end of the Union. Only than - only to avoid the complete collapse of the integration - the Union will be able to overcome national interests by overcoming national vetos.

The best (and possibly only) way to see the future of a deeper and wider Union in an optimistic light is to expect that the neo-functionalist understanding will prevail. The functional overflow plus the negative experience of effects of the standstill could provoke unwilling national governments to agree to a further power shift from the national to the European level. The functional overflow can best be explained by the "step after step" picture: The Community makes a step-e. g. it creates the Common Market. The Common Market implies, after the experience of a certain period, the need to establish the Single Market with its basic freedoms. The single Market leads to the Monetary Union. But the Monetary Union soon demonstrates the need of tax harmonisation. Integration is a chain of spillovers with not necessarily intended consequences.

This pattern of spillovers can be combined with the possible experience of shock. As soon as the result of the integration process is in jeopardy, even the representatives of national governments who are afraid to lose more and more power to the Union, could be inclined to accept a stronger (meaning: deeper) Union - as soon as it is obvious that the alternative to blockades by national vetos is the implosion of the EU. The 
European integration process at the brink of its collapse - this is, according to euro-optimists and neo-functionalists, the best hope for overcoming the present (and possible future) paralyses. Facing a catastrophe is the best way out to save the Union from disaster.

But this will only work if the standstill hurts really; if public opinion and the national constituencies are feeling fully the negative sides of a possible end of integration. First, the crisis must hurt; and only then the crisis may be overcome. The French and the Dutch referenda demonstrate that the crisis does not hurt enough - yet.

\section{The lack of a coherent Common Foreign and Security Policy is a possible catalyst the neo functionalists are looking for.}

From the very beginning, the European Communities have been perceived as an instrument for preventing war and safeguarding peace. The EU's peace function had an internal and an external aspect - overcoming the history of nationalistic warfare; and an external aspect - to be part of a western alliance, balancing the challenge coming from the east. Half of a century after the Rome Treaties have been signed, these peace functions have to be re-evaluated:

- Internal Peace: The EU guarantees peace among its member states. That part of the peace function has become the most important side of the union's success story. Warfare within the EU, among EU members, has become just unthinkable. The (economic and other) interests are a stable and predictable linkage binding the nation states to a common interest. After the brutal history of centuries of European wars, national warfare within the EU is just over.

- External Peace:The EU - out of its own security interests - has developed a Common Foreign and Security Policy (CFSP) after the end of the Cold War. Established by the Maastricht Treaty, streng- 
thened after the experience in the Balkan wars of the 1990s and by the take-over of the West European Union (WEU), the CFSP expresses the EU's interest to be a global actor in all matters concerning security. The EU has a declared interest to make its external peace function globally felt.

The CFSP is a promise - and, at the moment, not more. The best example to demonstrate the lack of efficiency has been the European position during the Iraq war, 2003. The US was able to act but the EU was not. Instead of the EU, member states acted - not combined by a common strategy, but acting against each other out of specific national interests: The UK and France, Germany and Poland, Spain and Sweden, Italy and Austria - it was a cacophony of national Egos; it was not a European concert.

No wonder that analysts like Robert Kagan ridiculed the EU by comparing the Europeans to the people of Liliput who in vain tried to control the American Gulliver. For the good or the bad, the US was speaking and acting as one power. The EU was not acting at all. The CFSP's structures, based on unanimity in the Council, did not permit the CFSP's "High Representative" to speak - and especially not to act. Europe had different, had contradicting voices - but Europe did not have a voice.

This has bee hurting: Europeans who opposed the war realised that the EU was structurally unable to do anything about the US dominance. Europeans backing the US-effort couldn't see any leverage whatsoever to make the Union siding with the US.

It is not about military spending. It is about integrating the already existing instruments the EU member states are in command of. To make Europe a significant actor in world politics - for the reason of balancing a presently dangerously unbalanced situation, the member states would have to agree to make the CFSP a common policy like other common policies - like agriculture, fisheries and transportation. The EU would have fulfil certain preconditions: 
- Institutionalized prerequisites are needed. The EU must be able to act even against the will of some member states. Qualified majority decision making in foreign policy matters is necessary to provide the EU with an institutional design permitting the Union to act.

- Specific instruments are needed. The CFSP must be based on a European military that is more than the cooperation between national militaries. The EU needs integrated European armed services.

- As long as the US (and others) can - rightly - distinguish between "old" and "new" Europe, between different national interests; as long as "old" and "new" Europe can be played against each other. Europe is not America's equal partner in world politics.

This concept of a CFSP beyond its present intergovernmental structure runs against certain interests:against the interests of the EU's two nuclear powers and permanent members of the UN Security Council, the UK and France, which are not interested to accept any kind of European control over their national power; against the interests of the neutral or non-aligned EU-members (Ireland, Sweden, Finland, Austria, Malta and Cyprus) not to permit majority decisions that could violate their status of neutrality. The concept of a strengthened CFSP is blocked by national interests.

\section{Enlargement makes deepening necessary}

- at but it also prevents deepening.

Widening has been one of the driving forces of European integration. After the complex enlargement of 2004 and the debate about membership negotiations with Turkey, the perspective of further enlargement has lost much of its mobilising qualities. The process of European integration has started as a West European community. In the meantime the EU has become almost a Pan-European Union. The enlargement process has reached certain limits. It has reached the borders of Europe. The borders 
are not clearly defined, but it is understood that at least east of Turkey, there is no Europe. And the enlargement has reached the limits of the mood of the European people (s) to accept always more and more newcomers to the Union.

It has been the clear understanding within the Union that the institutional arrangements for the EU must be changed before the enlargement of 2004 would take place. This would have been the task of the Nice Treaty of 2000. As the Treaty of Nice was considered far too short reaching for that purpose, the European Convention was established to provide the Union with such an arrangement before the effects of the enlargement of 2004 could be felt. The purpose of that arrangement - of the Constitution or Constitutional Treaty - was to enable the Union to function with 25 and more members. For that reason, the system of a strong national veto in the Council-designed for a Union of rather homogenous 6 members - should be sharply reduced in favour of significantly more qualified majority decisions in the Council and of more power for the European Parliament.

The result of the collapse of the constitution's ratification is that the enlarged Union of 25 has to live with a de facto constitution, the Treaty of Nice, that was clearly interpreted as an arrangement not to be sufficient for the enlarged Union. The present system's emphasis on the Council as the primary decision maker and the need to find unanimity in still so many important fields permits a specific characterisation of the EU's political system:It has been developed for a small Union with a rather small number of policies. It does not fit for a large Union with a large number of policies the Union has to deliver.

This contradiction stands in sharp contrast to the success story the European Union is: There has been practically no European state not wanting to join the $\mathrm{EU}$ - with the exception of some economically most privileged smaller nations like Norway or Switzerland. The Union has grown to an all-European community. Its combination of democracy and 
prosperity attracts especially those Europeans who are nor already in the Union. But the Union has outgrown its institutional design, its political system. That system is clearly not up-to-date; it is reflecting the Europe of the 1950s and 1960s.

This is an interesting paradox:From the outside, the EU is getting mostly positive feedback, especially from those nations willing to join. But from the inside, the Union seems to be paralysed - criticised from the far left and from the far right, used as a scapegoat for almost everything.

After the end of the Cold War, the world and especially Europe must be seen from the perspective of the success of liberal democracy. There is no universal challenge to that system. There are challenges to democracy - terrorism and fundamentalism of different creeds, for instance. But there is no consistent alternative any more able to claim a better future for all of mankind. In that respect, history - defined as the dialectic conflict of contradicting concepts - has come to an end. Democracy is thesis and synthesis of history.

Democratic Europe, now almost identical with the EU, has its share of that success. Democratic Europe profits from that success. The EU has given the continent peace and stability - due to democracy. But the EU itself has not grown internally with that success. The EU's political system is the system of the few for the few - and not the system of the many for the many. History may have come to an end-according to Francis Fukuyama. But the European integration is still a work in progress.

1) Moravcsik, Andrew: "The Choice for Europe. Social Purpose and State Power from Messina to Maastricht". Ithaca, NY 1998 (Touchstone).

2) Nicolaidis, Kalypso; Howse, Robert (eds.): "The Federal Vision. Legitimacy and Levels of Government in the United States and the European Union". Oxford 2001 (Oxford University Press). 
3) Oudenaren, John van: "Uniting Europe. An Introduction to the European Union". Second Edition. Lanham, MD 2005 (Rowman \& Littelfield), pp. $234 \mathrm{f}$.

4) Oudenaren, op. cit., pp. 56 f.

5) Oudenaren, op. cit., pp. 71-96.

6) Scharpf, Fritz W.: "Democratic Legitimacy under Conditions of Regulatory Competition: Why Europe differs from the United States." In: Nicolaidis, Howse, op. cit., pp. 355-374.

7) Whitaker, Richard: "National Parties in the European Parliament. An Influence in the Committee System ?” In : European Union Politics, vol. 6, March 2005, pp. 28.

8 ) Oudenaren, op. cit., pp. 354-362.

9) Huntington, Samuel P.: "The Clash of Civilisations and the Remaking of World Order". London 1998 (Touchstone Books).

10) Rupnik, Jacques (ed.): “Les Européens face à l'élargissement. Perceptions, acteurs, enjeux. Paris 2004 (Presses de Sciences Po).

11) Oudenaren, op. cit., p. 298.

12) Nugent, Neill: “The Government and Politics of the European Union". Fourth edition. Durham, NC 1999 (Duke University Press), pp. 491-519.

13) Oudenaren, op. cit., p. 24.

14) Odenaren, op. cit., pp. 295-335.

15) Kagan, Robert: "Paradise and Power. America and Europe in the New World Order". London 2004 (Atlantic Books).

16) Oudenaren, op. cit., pp. 65-67.

17) Fukuyama, Francis: "The End of History and the Last Man". New York, NY 2002 (Perennial). 


\section{Summary}

\section{Governance in the European Union}

\section{Anton Pelinka}

The paper argues that the EU and its political system are a special case between a federal system (like the US) and an international organisation (like the UN). This can be exemplified by the interests behind the EU's three main institutions - Council, Commission, and Parliament. It is especially the Council and the veto power each member state enjoys in still many decisive fields that prevents the EU from becoming a federation. The lack of an integrated party system indicates the "unfinished" status of the Union - but at the same time, that lack is one of the reasons why the process towards a deeper Union is not going on faster. The paralysis of the deepening process, caused by the French and Dutch constitutional veto, underlines the contradiction of the EU which is more than a confederation but clearly not (yet?) a federation. The paper argues that the paralysis can be interpreted in a more optimistic way only from the viewpoint of neo-functionalism in combination with the brinkmanship-argument: The integration process will go on-only or especially, when the result of the whole integration, that is the EU itself, is in jeopardy. The lack of a coherent und substantive Common Foreign and Security Policy (CFSP) can provide the Union with such a shocking (and hurting) experience, but also the need to deepen the Union not 
despite but because of the enlargement of 2004. The Union is a paradox: Hugely popular for those who are still outside but have some reason to hope to join; but less popular for the insiders as could be seen in the referenda in France and in the Netherlands in 2005. Part of this paradox is the unholy alliance between rightist nationalists and leftist anticapitalists united by nothing else but by the EU as a common enemy. 